\title{
Glutamate Receptors on Myelinated Spinal Cord Axons: I. GluR6 Kainate Receptors
}

\author{
Mohamed Ouardouz, PhD, ${ }^{1}$ Elaine Coderre, ${ }^{1}$ Ajoy Basak, PhD, ${ }^{2}$ Andrew Chen, BSc, ${ }^{2}$ \\ Gerald W. Zamponi, PhD, ${ }^{3}$ Shameed Hameed, PhD, ${ }^{3}$ Renata Rehak, MSc, ${ }^{3}$ Xinghua Yin, MD, ${ }^{4}$ \\ Bruce D. Trapp, PhD, ${ }^{4}$ and Peter K. Stys, $\mathrm{MD}^{5}$
}

\begin{abstract}
Objective: The deleterious effects of glutamate excitotoxicity are well described for central nervous system gray matter. Although overactivation of glutamate receptors also contributes to axonal injury, the mechanisms are poorly understood. Our goal was to elucidate the mechanisms of kainate receptor-dependent axonal $\mathrm{Ca}^{2+}$ deregulation.

Methods: Dorsal column axons were loaded with a $\mathrm{Ca}^{2+}$ indicator and imaged in vitro using confocal laser-scanning microscopy.

Results: Activation of glutamate receptor 6 (GluR6) kainate receptors promoted a substantial increase in axonal [Ca ${ }^{2+}$ ]. This $\mathrm{Ca}^{2+}$ accumulation was due not only to influx from the extracellular space, but a significant component originated from ryanodine-dependent intracellular stores, which, in turn, depended on activation of L-type $\mathrm{Ca}^{2+}$ channels: ryanodine, nimodipine, or nifedipine blocked the agonist-induced $\mathrm{Ca}^{2+}$ increase. Also, GluR6 stimulation induced intraaxonal production of nitric oxide (NO), which greatly enhanced the $\mathrm{Ca}^{2+}$ response: quenching of $\mathrm{NO}$ with intraaxonal (but not extracellular) scavengers, or inhibition of neuronal NO synthase with intraaxonal $\mathrm{N} \omega$-nitro-L-arginine methyl ester, blocked the $\mathrm{Ca}^{2+}$ increase. Loading axons with a peptide that mimics the C-terminal PDZ binding sequence of GluR6, thus interfering with the coupling of GluR6 to downstream effectors, greatly reduced the agonist-induced axonal $\mathrm{Ca}^{2+}$ increase. Immunohistochemistry showed $\mathrm{GluR6/7}$ clusters on the axolemma colocalized with neuronal $\mathrm{NO}$ synthase and $\mathrm{Ca}_{\mathrm{v}} 1.2$.

Interpretation: Myelinated spinal axons express functional GluR6-containing kainate receptors, forming part of novel signaling complexes reminiscent of postsynaptic membranes of glutamatergic synapses. The ability of such axonal "nanocomplexes" to release toxic amounts of $\mathrm{Ca}^{2+}$ may represent a key mechanism of axonal degeneration in disorders such as multiple sclerosis where abnormal accumulation of glutamate and $\mathrm{NO}$ are known to occur.
\end{abstract}

Ann Neurol 2009;65:151-159

Glutamate is the main excitatory neurotransmitter in the mammalian central nervous system, playing a significant role in gray matter injury in many neurodegenerative diseases. ${ }^{1}$ Prevalent and devastating disorders such as stroke, multiple sclerosis, and trauma to the brain and spinal cord invariably affect afferent and efferent white matter tracts, though much less is known about mechanisms of injury to myelinated white matter axons. Voltage-gated $\mathrm{Na}^{+}$and $\mathrm{Ca}^{2+}$ channels, together with reverse $\mathrm{Na}^{+}-\mathrm{Ca}^{2+}$ exchange, play important roles ${ }^{2-4}$ (for review, see Stys ${ }^{5}$ ). Perhaps counterintuitive, given the nonsynaptic nature of central nervous system white matter, are observations of functional protection of this tissue by antagonists of ionotropic glutamate receptors. $\alpha$-amino-3-hydroxy-5-methyl-4isoxazole propionic acid (AMPA)/kainate receptor antagonists are protective both in vitro ${ }^{6-10}$ and in vivo, ${ }^{11-14}$ in ischemic, traumatic, and autoimmune models of white matter injury. Conversely, activating AMPA/kainate receptors, but not $N$-methyl-D-aspartate (NMDA) receptors, or increasing extracellular glutamate levels by blocking glutamate transport either in vitro $^{15-17}$ or in vivo ${ }^{17-19}$ is injurious to axons.

The precise mechanisms of injury to white matter elements induced by non-NMDA glutamate receptor activation are unknown. Both astrocytes and oligodendrocytes express AMPA and kainate receptors (for review, see Matute and colleagues ${ }^{20}$ ), and more recently,
From the ${ }^{1}$ Division of Neuroscience and ${ }^{2}$ Hormones, Growth and Development Program, Ottawa Health Research Institute, University of Ottawa, Ottawa, Ontario; ${ }^{3}$ Department of Physiology and Biophysics, Hotchkiss Brain Institute, University of Calgary, Calgary, Alberta, Canada; ${ }^{4}$ Department of Neurosciences, Cleveland Clinic Foundation, Cleveland, $\mathrm{OH}$; and ${ }^{5}$ Department of Clinical Neurosciences, Hotchkiss Brain Institute, University of Calgary, Calgary, Alberta, Canada.

Address correspondence to Dr Stys, Department of Clinical Neurosciences, HRIC 1AA22, 3330 Hospital Drive NW, AB, Canada, T2N 4N1. E-mail: pstys@ucalgary.ca
Potential conflict of interest: Nothing to report.

Received Jun 17, 2008, and in revised form Aug 5. Accepted for publication Aug 21, 2008.

Published online in Wiley InterScience (www.interscience.wiley.com). DOI: 10.1002 /ana.21533

Additional Supporting Information may be found in the online version of this article. 
NMDA receptors have been detected on mature oligodendrocytes, ${ }^{21}$ their processes, ${ }^{22}$ and even the myelin sheath. ${ }^{23}$ These receptors are permeable to $\mathrm{Ca}^{2+}$ ions; therefore, it is reasonable to conclude that receptormediated $\mathrm{Ca}^{2+}$ overload is responsible for excitotoxic glial injury. ${ }^{15,24,25}$ What is so far unexplained is the observation that central axons per se are damaged by activation of AMPA/kainate receptors ${ }^{18,19}$ and, in turn, protected by blockers of these receptors in various injury models. ${ }^{9,13,26}$ These latter observations raise the possibility that central myelinated axons themselves express AMPA/kainate receptors, whose overactivation results in damage to the fibers directly. Indeed, antagonists of AMPA/kainate receptors, but not NMDA receptors, were protective against spinal cord dorsal column injury, ${ }^{6-8}$ and bath application of AMPA, kainate, or glutamate, but not NMDA, induced irreversible reduction of compound action potential. ${ }^{6,16}$ In this report, we tested the hypothesis that myelinated axons from rat spinal cord express functional kainate receptors capable of mediating a potentially deleterious axonal $\mathrm{Ca}^{2+}$ increase. We found that GluR6containing kainate receptors reside along the internodal axolemma in "nanocomplexes" together with neuronal nitric oxide synthase (nNOS), exerting control over L-type $\mathrm{Ca}^{2+}$ channels and causing $\mathrm{Ca}^{2+}$ release from intraaxonal $\mathrm{Ca}^{2+}$ stores. These signaling molecules are organized in a surprisingly intricate arrangement (see Fig 6) reminiscent of what is found at the postsynaptic membrane of conventional glutamatergic synapses.

\section{Materials and Methods}

All experiments were performed in accordance with institutional guidelines for the care and use of experimental animals. Additional details can be found in the supplementary material.

\section{$\mathrm{Ca}^{2+}$ Imaging}

Dorsal columns from deeply anesthetized adult Long-Evans male rats were removed from the thoracic region and placed in cold, oxygenated zero- $\mathrm{Ca}^{2+}$ solution (containing in $\mathrm{mM}$ : $\mathrm{NaCl}$ 126, $\mathrm{KCl} 3, \mathrm{MgSO} 4$ 2, NaHCO3 26, NaH2PO4 $1.25, \mathrm{MgCl} 22$, dextrose 10 and EGTA 0.5, oxygenated with 95\% O2/5\% CO2), loaded for 2 hours with $\mathrm{Ca}^{2+}$ insensitive reference dye (red dextran-conjugated Alexa 594, $250 \mu \mathrm{M}$ ) to allow identification of axon profiles (Fig 1A), together with the dextran-conjugated $\mathrm{Ca}^{2+}$ indicator Oregon Green BAPTA-1 $(250 \mu \mathrm{M})$, and imaged on a Nikon C1 (Toronto, Ontario) confocal microscope at $37^{\circ} \mathrm{C}$. All reported axonal $\left[\mathrm{Ca}^{2+}\right]$ changes $\left(\mathrm{F}_{\mathrm{Ca} \text {.ax }}\right)$ are ratios of green to red fluorescence after 30 minutes of drug application.

\section{Immunochemistry and Immunoelectron Microscopy}

Immunohistochemistry, immunoelectron microscopy, and immunochemistry were performed using standard techniques $^{23}$ (see supplemental material).

\section{Peptide Synthesis and Purification}

Two peptides ( $\mathrm{NH}_{2}$-Cys-Ahx-Arg-Leu-Pro-Gly-Lys-GluThr-Met-Ala-CONH ${ }_{2}(\mathrm{I})$, [molecular weight $=1,218$ ] and $\mathrm{NH}_{2}$-Cys-Ahx-Cys-Ahx-Cys-Ahx-Cys-Ahx-Arg-Leu-Pro-GlyLys-Glu-Thr-Met-Ala-CONH ${ }_{2}$ (II) [molecular weight = $1,864]$ ) were designed that contain the C-terminal of GluR6 PDZ1 binding motif, a single or multiple N-terminal Cys residues (for dye conjugation via free $\mathrm{SH}$ groups), and one or more Ahx ( $\varepsilon$-amino-hexanoic acid) moieties as spacers (for steric reasons). Active and sham dextropeptides were synthesized using standard methods. The peptides were dissolved to a concentration of 0.1 to $1 \mathrm{mM}$ in the loading pipette yielding approximately 1 to $10 \mu \mathrm{M}$ in the axons.

\section{Results}

\section{Activation of GluR6-Containing Receptors Increases Axonal $\mathrm{Ca}^{2+}$}

We measured $\left[\mathrm{Ca}^{2+}\right]$ changes in live adult rat dorsal column axons in vitro using laser-scanning confocal microscopy (see Fig 1). Activation of kainate receptors (kainate $200 \mu \mathrm{M}$ ), at concentrations that significantly reduced compound action potentials (see later), caused a progressive increase of intraaxonal $\left[\mathrm{Ca}^{2+}\right]$. Axoplasmic $\mathrm{Ca}^{2+}$-dependent fluorescence $\left(\mathrm{F}_{\text {Ca.ax }}\right)$ showed a robust increase after drug application (mean increase after 30 minutes: kainate, $110 \pm 67 \%$; $n=54$ axons) that was strongly reduced by the AMPA/kainate receptor antagonist 6-cyano-7-nitroquinoxaline-2,3-dione (CNQX $50 \mu \mathrm{M})(12 \pm 15 \% ; \mathrm{n}=35 ; p \approx 0)$. The AMPA receptor antagonists 1 -naphtyl acetyl spermine $(25 \mu \mathrm{M})$ or 1-(4-aminophenyl)-4-methyl-7,8-methylenedioxy-5H-

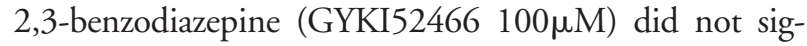
nificantly blunt kainate-induced $\mathrm{F}_{\text {Ca.ax }}$ increase (kainate + spermine: $97 \pm 64 \%, \mathrm{n}=54, p=0.98$; kainate + GYKI52466: $79 \pm 65 \%, \mathrm{n}=40, p=0.24)$. In contrast, 3-(hydroxyamino)-6-nitro-6,7,8,9tetrahydrobenzo[g]indol-2-one (NS-102 $10 \mu \mathrm{M}$ ), an antagonist of GluR6-containing kainate receptors, ${ }^{27}$ strongly reduced the response induced by kainate (kainate + NS-102: $35 \pm 25 \%$; $=37 ; p \approx 0)$. (S)-1-(2amino-2-carboxyethyl)-3-(2-carboxybenzyl)pyrimidine2,4-dione (UPB-302, $20 \mu \mathrm{M}$ ), a blocker of GluR5containing kainate receptors, ${ }^{28}$ was less effective (kainate + UPB-302: $74 \pm 40 \%$; $=36$ ) than CNQX or NS-102 at blocking the kainate-induced $\mathrm{Ca}^{2+}$ responses $(p \leq 0.012$, kainate $+\mathrm{UPB}-302$ vs kainate + CNQX or kainate + NS-102) (see Fig 1C), indicating that kainate mainly (but not exclusively) activated kainate receptors containing GluR6 subunits. (2S,4R)-4methyl glutamic acid (SYM2081; 100 $\mu \mathrm{M}$ ), another kainate receptor agonist, ${ }^{29}$ induced an increase of $\mathrm{F}_{\text {Ca.ax }}$ $(135 \pm 67 \% ; n=79)$ with a similar pharmacological profile to kainate: The $\mathrm{Ca}^{2+}$ response was reduced by CNQX (SYM2081 + CNQX: $38 \pm 24 \% ; \mathrm{n}=29$; $\left.p=4 \times 10^{-10}\right)$ and NS102 $(25 \pm 35 \% ; \mathrm{n}=28 ; p=$ $\left.4 \times 10^{-10}\right)$, and also was modestly reduced by 


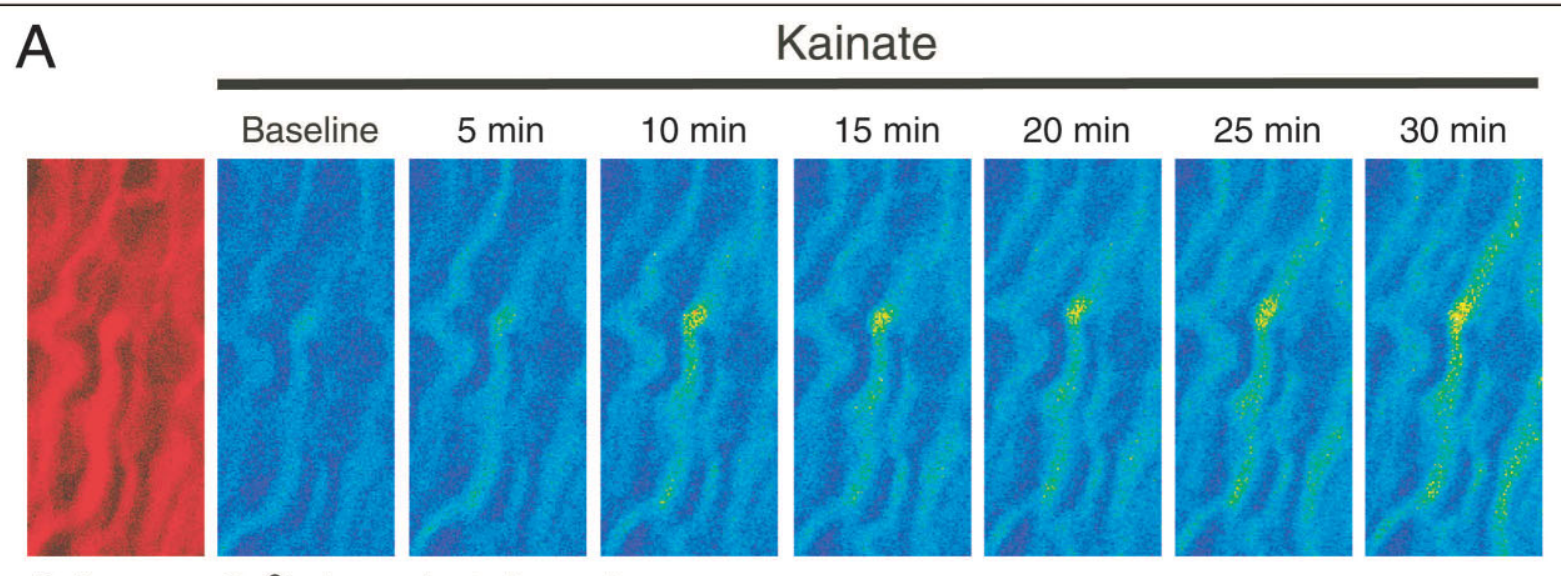

Reference $\mathrm{Ca}^{2+}$-dependent channel
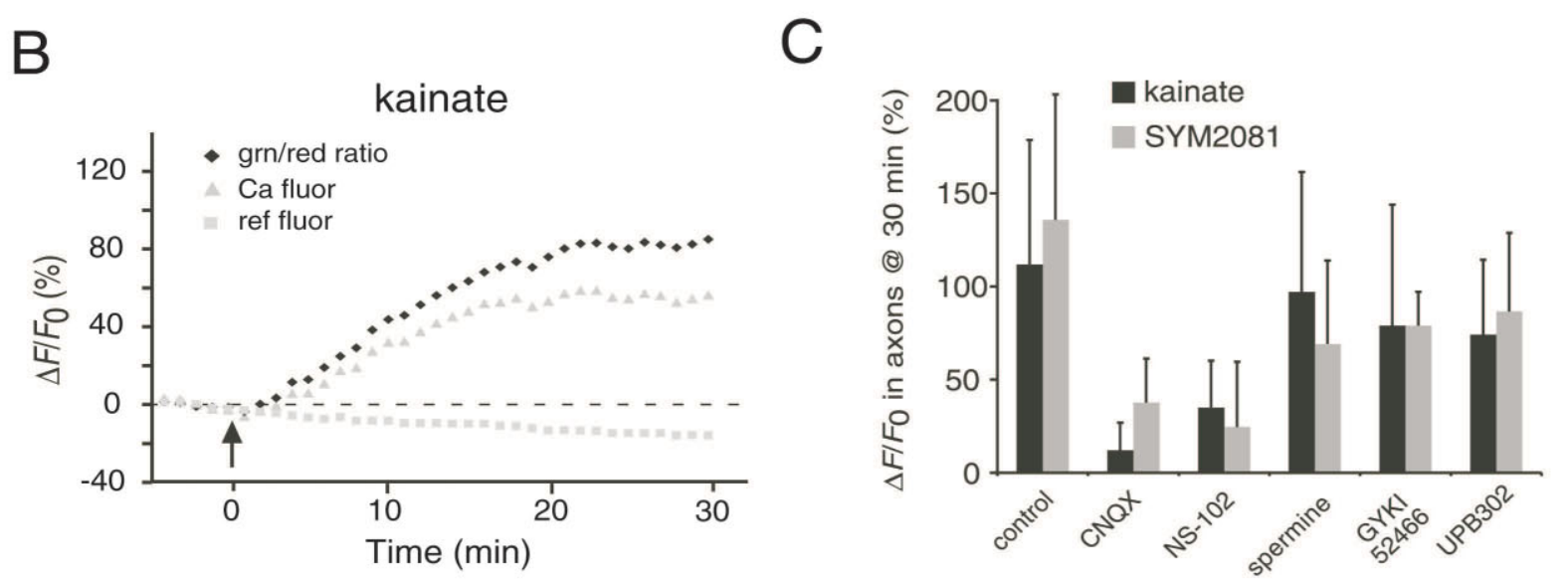

Fig 1. $\left[\mathrm{Ca}^{2+}\right]$ in dorsal column axons in response to kainate receptor activation. (A) Confocal micrographs of axons loaded with red dextran-conjugated reference dye together with the $\mathrm{Ca}^{2+}$ indicator Oregon Green-488 BAPTA-1 shown in pseudocolor. Activating kainate receptors with kainate induced an increase in $\mathrm{Ca}^{2+}$-dependent fluorescence in the axoplasm. (B) Representative time course of axonal $\mathrm{Ca}^{2+}$ increase in response to bath application of agonist at time zero (arrow). Black diamonds represent green/red ratio; gray triangles represent $C a$ fluorescence; and gray squares represent reference fluorescence. (C) Bar graph showing mean percentage change ( \pm standard deviation) in axonal $\mathrm{Ca}^{2+}$-dependent fluorescence after 30 minutes of agonist exposure and also effects of antagonists. Blockers of GluR6-containing receptors (CNQX and NS-102) were far more effective at reducing Ca ${ }^{2+}$ increase induced by kainate or SYM2081 than AMPA (spermine, GYKI52466) or GluR5 (UPB302) antagonists.

1-naphthyl acetyl spermine $(79 \pm 37 \% ; \mathrm{n}=49 ; p=$ $\left.4 \times 10^{-10}\right)$ or GYKI52466 $(83 \pm 18 \% ; \mathrm{n}=20 ; p=$ $\left.7 \times 10^{-10}\right)$, suggesting a partial activation of AMPA receptors by the latter agent at the concentrations used. UPB-302 was also less effective at blocking the SYM 2081 response $(94 \pm 40 \%$; $=17)$.

$\mathrm{Ca}^{2+}$ Stores Contribute to GluR6-Dependent Axonal $\mathrm{Ca}^{2+}$ Increase

To further characterize the sources of axonal $\mathrm{Ca}^{2+}$ increase, we applied agonists in the absence of bath $\mathrm{Ca}^{2+}$ $(+0.5 \mathrm{mM}$ EGTA), which reduced but did not completely prevent $\mathrm{F}_{\text {Ca.ax }}$ increase (kainate $+0 \mathrm{Ca}^{2+}: 26 \pm$ $20 \%, \mathrm{n}=33, p \approx 0 \mathrm{vs} \mathrm{Ca}^{2+}$-containing perfusate; SYM2081 $+0 \mathrm{Ca}^{2+}: 42 \pm 31 \%, \mathrm{n}=24, p=4 \times$ $\left.10^{-10}\right)$. This suggests that a component of the kainate receptor-induced axonal $\mathrm{Ca}^{2+}$ increase originated from intracellular compartments. Previously, we reported that ischemic depolarization of spinal axons releases $\mathrm{Ca}^{2+}$ from ryanodine-dependent axonal $\mathrm{Ca}^{2+}$ stores. ${ }^{30}$ We therefore examined whether kainate receptors might induce $\mathrm{Ca}^{2+}$ release from these stores. Ryanodine $\left(50 \mu \mathrm{M}\right.$, in $\mathrm{Ca}^{2+}$-replete perfusate) almost completely blocked the $\mathrm{F}_{\text {Ca.ax }}$ increase (kainate + ryanodine: $2 \pm 22 \%, \mathrm{n}=33, p=0$ vs kainate alone; SYM2081 + ryanodine: $11 \pm 28 \%, \mathrm{n}=27, p=4 \times$ $10^{-10}$ ), indicating that most of the axonal $\mathrm{Ca}^{2+}$ accumulation observed in response to kainate receptor activation originated from axonal ryanodine-sensitive $\mathrm{Ca}^{2+}$ stores (Fig 2A). More surprisingly, blockade of L-type $\mathrm{Ca}^{2+}$ channels by nimodipine or nifedipine $(10 \mu \mathrm{M})$ also strongly inhibited axoplasmic $\mathrm{Ca}^{2+}$ increase (kainate + nimodipine: $6 \pm 19 \%, \mathrm{n}=26, p \approx$ 0 vs kainate alone; SYM2081 + nimodipine: $17 \pm$ 


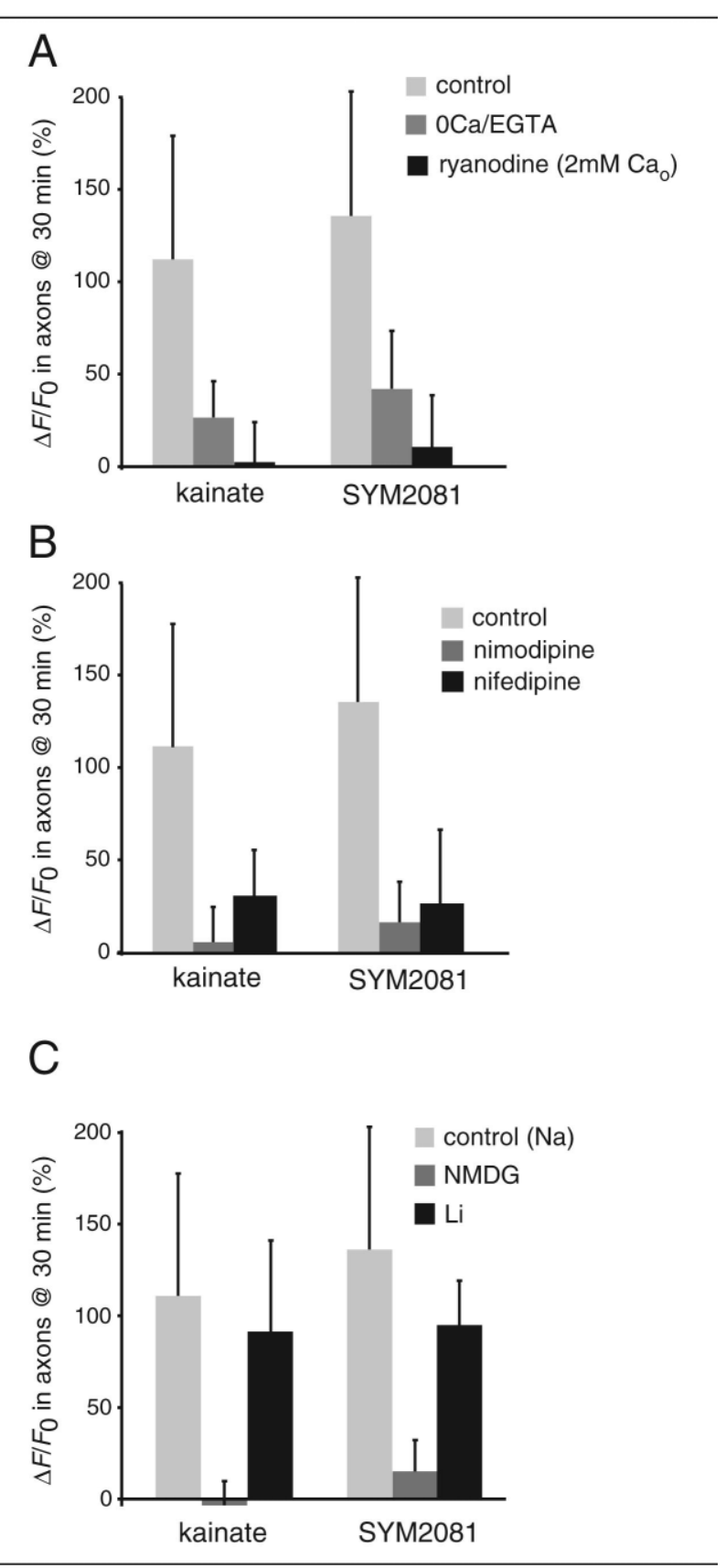

Fig 2. Kainate receptors promote $\mathrm{Ca}^{2+}$ release from internal stores. (A) $\mathrm{Ca}^{2+}$-free perfusate reduced but did not eliminate agonist-induced $\mathrm{Ca}^{2+}$ increase. Blocking of ryanodine receptors (ryanodine) strongly reduced $\mathrm{Ca}^{2+}$ response even in the presence of $2 \mathrm{mM}$ bath $\mathrm{Ca}^{2+}$, suggesting that most of the agonistinduced $\mathrm{Ca}^{2+}$ increase was due to release from ryanodinesensitive $\mathrm{Ca}^{2+}$ stores, rather than from influx across the axolemma. (B) L-type $\mathrm{Ca}^{2+}$ channel antagonists (nimodipine, nifedipine) selectively reduced responses induced by kainate or SYM2081. (C) Kainate receptor-dependent axonal $\mathrm{Ca}^{2+}$ increase depended on permeable ions such as $\mathrm{Na}^{+}$or $\mathrm{Li}^{+}$but was blocked by impermeable N-methyl-D-glucamine (NMDG). Error bars represent standard deviation.
$22 \%, \mathrm{n}=43, p=4 \times 10^{-10}$ ) (see Fig 2B). L-type $\mathrm{Ca}^{2+}$ channels may, in turn, be modulated by a local membrane depolarization or possibly even by a metabotropic action of kainate receptors. ${ }^{31}$ Replacing $\mathrm{NaCl}$ with impermeant $N$-methyl-D-glucamine chloride (NMDG-Cl) to reduce putative agonist-induced axonal depolarization virtually abolished kainate- (kainate + NMDG: $-5 \pm 13 \%, \mathrm{n}=37, p \approx 0$ vs $\mathrm{Na}^{+}$containing perfusate) and SYM2081-induced $\mathrm{Ca}^{2+}$ increase (SYM2081 + NMDG: $15 \pm 17 \%, \mathrm{n}=32$, $\left.p=1.7 \times 10^{-10}\right)$. Substitution of $\mathrm{NaCl}$ with $\mathrm{LiCl}$, which readily permeates kainate receptors, ${ }^{32}$ allowed a robust axonal $\mathrm{Ca}^{2+}$ increase after application of kainate $(91 \pm 50 \% ; n=52)$ or SYM2081 (95 $\mathrm{n}=24 \% ; \mathrm{n}=$ 34) (see Fig 2C). Taken together, these data suggest that GluR6-containing kainate receptors mediate their actions through a combination of local membrane depolarization and a small influx of $\mathrm{Ca}^{2+}$ triggering a larger release from ryanodine-sensitive $\mathrm{Ca}^{2+}$ stores.

\section{Intraaxonal Nitric Oxide Generation Promotes the $\mathrm{Ca}^{2+}$ Increase}

Although the earlier results support the involvement of kainate receptors in the mobilization of $\mathrm{Ca}^{2+}$, they do not prove that these receptors are necessarily axonal; indeed, the protective effects of AMPA/kainate antagonists in white matter injury was suggested to be due to protection of glial elements ${ }^{33}$ with indirect sparing of axons (for review, see Matute and colleagues ${ }^{34}$ ). The experiments shown in Figure 3A, relying on selective extracellular versus intraaxonal application of scavengers, strongly suggest that kainate receptors are expressed directly on axons and stimulate formation of nitric oxide (NO) within axons, which, in turn, promotes the above $\mathrm{Ca}^{2+}$ release cascade. Bath application of the NO scavenger myoglobin ${ }^{35}$ failed to prevent axoplasmic $\mathrm{Ca}^{2+}$ increase (kainate + myoglobin: $80 \pm$ $66 \%, \mathrm{n}=27, p=0.2$ vs kainate alone; SYM2081 + myoglobin: $145 \pm 49 \%, \mathrm{n}=34, p \approx 1$ ). Hydroxocobalamin, another $\mathrm{NO}$ scavenger $^{36}$ with a much smaller molecular weight (and, therefore, more readily able to permeate small interstitial spaces between axons, but nevertheless membrane impermeable), was equally ineffective (kainate + hydroxocobalamin: $90 \pm$ $71 \%, \mathrm{n}=23, p=0.94$ vs kainate alone). These experiments indicate that NO synthesized outside the axon did not play a role in kainate receptor-mediated $\mathrm{Ca}^{2+}$ release inside axons. To explore whether intraaxonally generated NO may be important, we selectively loaded myoglobin into axons. In contrast with bath application, intraaxonal scavenger potently blocked kainate- $(0 \pm 22 \% ; \mathrm{n}=22)$ and SYM2081-induced $(16 \pm 33 \% ; \mathrm{n}=25) \mathrm{Ca}^{2+}$ responses $(p \approx 0)$. Intraaxonal hydroxocobalamin was also highly effective, as was the nitric oxide synthase inhibitor L-NAME $(p \approx$ $0)$. Moreover, the effect of intraaxonal NO was syner- 


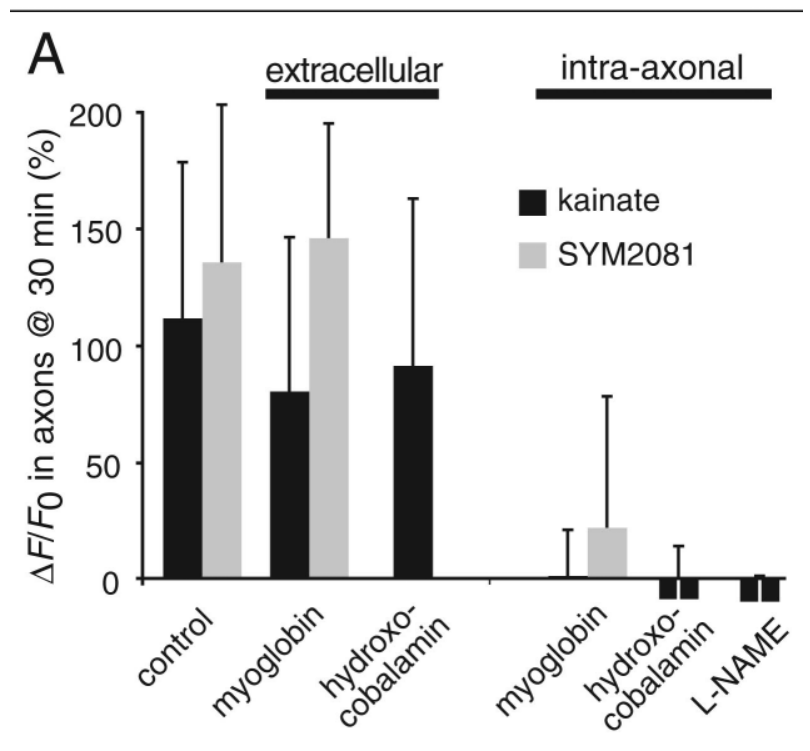

which was greatly reduced by either nimodipine or ryanodine.

\section{Axonal Signaling "Nanocomplexes" Containing GluR6/7, Neuronal Nitric Oxide Synthase, and $C a_{v} 1.2$}

The previous observations suggest a close relation between axonally expressed GluR6 kainate receptors and nitric oxide synthase. Immunohistochemistry was performed to further localize these receptors and their associated signaling proteins (Fig 4). Punctate staining for GluR6/7 (using two different primary antibodies from different species) and nNOS was observed at the periphery of neurofilament-labeled axon cylinders. These clusters were often, but not invariably, colocalized. Although we did not attempt to examine the frequency of these complexes along the length of an axon, the representative micrograph in Figures $4 \mathrm{~A}$ to $\mathrm{C}$ suggests that at least several clusters are present per internode. Immunoelectron microscopy localized GluR6/7 to the axolemma and to clusters beneath the axolemma. Consistent with earlier pharmacological evidence pointing to a functional interaction between kainate receptors and L-type $\mathrm{Ca}^{2+}$ channels, colocalized GluR6/7 and $\mathrm{Ca}_{\mathrm{v}} 1.2$ clusters were also observed at the surfaces of axons (see Figs $4 \mathrm{E}-\mathrm{G}$ ). Immunoprecipitation of dorsal column lysate with the GluR6/7 antibody yielded a single nNOS-positive band indicating a physical association between this kainate receptor and the enzyme (see Fig 4I). We further hypothesized that a PDZ-binding motif on the $\mathrm{C}$ terminus of GluR6 may mediate an interaction between this receptor and an adaptor protein, ${ }^{37}$ which, in turn, may scaffold the receptor in proximity to axonal nNOS to support a functional relation. We constructed a peptide comprising the nine C-terminal residues of GluR6 (RLPGKETMA, see Materials and Methods), to interfere with such a putative interaction. When this peptide was loaded into axons, both kainate and SYM2081 $\mathrm{Ca}^{2+}$ responses were almost completely blocked (kainate + peptide: $12 \pm 28 \%, \mathrm{n}=77, p=1.2 \times 10^{-5}$ vs kainate alone; SYM2081 + peptide: $13 \pm 27 \%$, $\left.\mathrm{n}=78, p=1.1 \times 10^{-5}\right)$. A sham peptide had little effect on the $\mathrm{Ca}^{2+}$ increase induced by kainate $(91 \pm$ $28 \% \mathrm{n}=45)$ or SYM2081 $(96 \pm 30 \% ; \mathrm{n}=42)$; the responses with the active compared with the sham peptides were highly significantly different $\left(p<10^{-9}\right.$ for both agonists) (Fig 5A). Further proof of an intraaxonal localization of a GluR6-PDZ domain, which could scaffold this receptor within a signaling nanocomplex containing nNOS, was obtained by loading the synthetic interfering peptide, itself labeled with multiple fluorescent moieties, into axons. As with the fixed immunohistochemical sections, we observed occasional punctate clusters of fluorescent peptide at the periphery of fluorescein-dextran-loaded axons (see Figs 

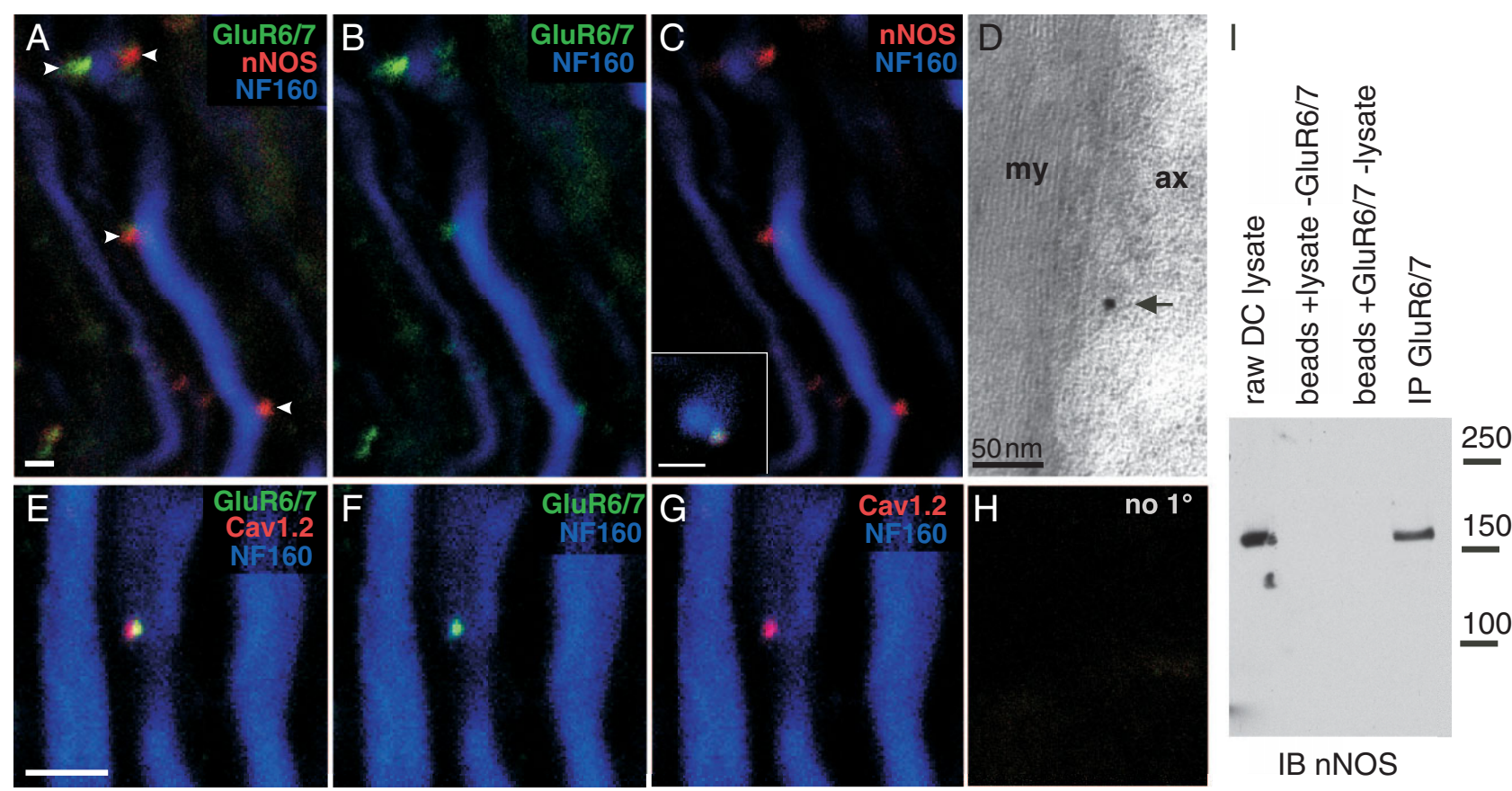

IB nNOS

Fig 4. Multimolecular "nanocomplexes" containing several signaling proteins are present in the internodal axolemma. (A-C) Tripleimmunolabeled dorsal column axons showing occasional punctate regions of colocalized glutamate receptors 6 and 7 (GluR6/7) and neuronal nitric oxide synthase ( $n N O S$ ) clusters (arrowheads) at the surface of neurofilament-stained axon cylinders. (inset) Transverse view of a surface cluster in another fiber. (D) Immunogold labeling using GluR6/7 primary antibody showing signal at the axolemma in a myelinated internode (arrow). my = myelin; $a x=$ axon. Consistent with pharmacological manipulations and Ca ${ }^{2+}$ imaging (see Fig. 2), GluR6/7-containing clusters also colocalized with Cav 1.2 L-type Ca ${ }^{2+}$ channels (E-G). (H) Representative control section with primary antibodies omitted showed little nonspecific labeling. Scale bars $2 \mu m$. (I) GluR6/7 antibody immunoprecipitated nNOS as shown by the single nNOS-positive band at the expected molecular weight (IP GluR6/7). nNOS was also detected by straight immunoblotting in dorsal column lysate (raw DC lysate). As expected, control experiments with beads + lysate (without GluR6/7) or beads + GluR6/7 (without lysate) showed no nNOS signal (molecular weight markers in kilodaltons).

5B-D), consistent with the notion that these fibers contain discrete clusters of PDZ domains able to bind and likely cluster kainate receptors.

\section{GluR6 Activation Causes Functional Dorsal Column Injury}

Having identified such an arrangement of internodal signaling protein clusters capable of significantly increasing axonal $\mathrm{Ca}^{2+}$ levels, we then explored whether such persistent increases of $\mathrm{Ca}^{2+}$ had any functional implications in otherwise uninjured dorsal columns. Propagated compound action potentials were recorded electrophysiologically, and functional integrity of this white matter tract was determined by calculating the area under the digitized responses. ${ }^{38}$ Exposure of dorsal columns to kainate $(200 \mu \mathrm{M})$ or SYM2081 $(100 \mu \mathrm{M})$ for 60 minutes followed by a 3-hour wash caused an irreversible reduction of mean compound action potential (CAP) area to approximately $60 \%$ of control (data not shown). Addition of the L-type $\mathrm{Ca}^{2+}$ channel blocker nimodipine $(10 \mu \mathrm{M})$ significantly protected against kainate- (CAP area recovery: kainate + nimodipine, $93 \pm 17 \%, \mathrm{n}=8$, vs kainate alone, $68 \pm$
$10 \%, \mathrm{n}=8 ; p=0.003$, Wilcoxon rank test) and SYM2081-induced injury (SYM2081 + nimodipine, $83 \pm 23, \mathrm{n}=9$, vs SYM2081 alone, $51 \pm 15, \mathrm{n}=7$; $p=0.0022)$.

\section{Discussion}

A number of in vitro and in vivo studies have pointed to an important role for non-NMDA glutamate receptors in white matter injury, ${ }^{6,8,9,16}$ with glial cells representing an important target given their known expression of AMPA and kainate receptors, ${ }^{20}$ and their sensitivity to this excitotoxin. ${ }^{24,39}$ This sensitivity to AMPA/kainate receptor activation also applies to immature oligodendrocyte precursors. ${ }^{40}$ Glutamate is released from injured myelinated axons via reverse $\mathrm{Na}^{+}$dependent glutamate transport ${ }^{7}$ and via vesicular release from unmyelinated fibers during physiological activation. ${ }^{41,42}$ In contrast, little is known about functional glutamate receptors on central axons, though experiments indirectly suggest that such receptors may be present. ${ }^{8,43}$

Here we show that functional kainate receptors are present on myelinated central axons, raising the dis- 

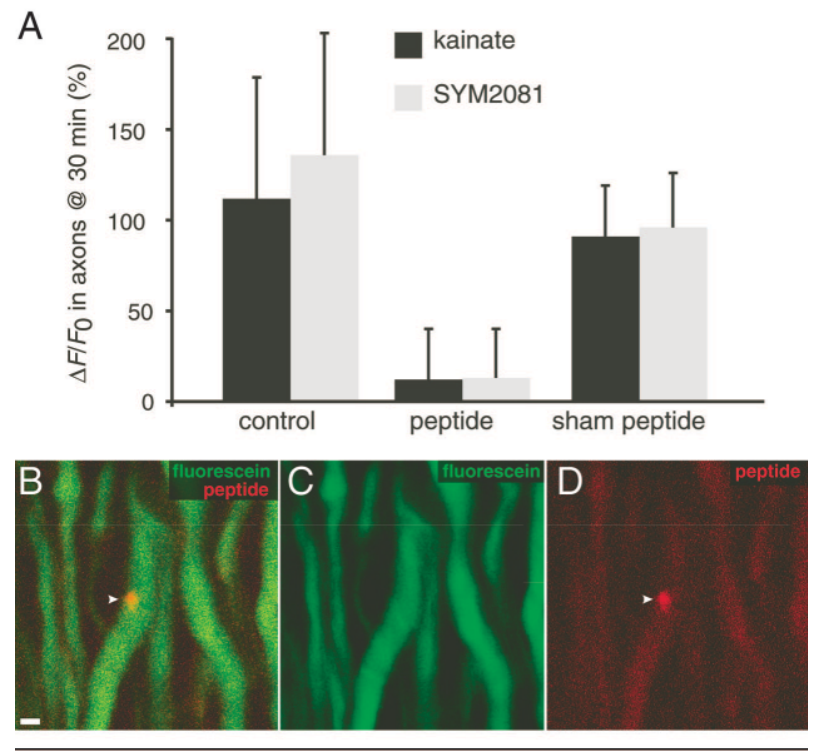

Fig 5. Infusing a peptide into axons that interfere with the binding of GluRG to PDZ domains greatly reduced the $\mathrm{Ca}^{2+}$ response, whereas a sham peptide with the same sequence but synthesized using unnatural D-amino acids was far less effective (A). (B-D) Live spinal axons were coloaded with dextran fluorescein and Texas Red-conjugated peptide that recognizes a $P D Z$ binding domain. Arrowhead shows a cluster of fluorescent peptide labeling an intraaxonal PDZ domain-containing protein complex. Scale bar $=2 \mu \mathrm{m}$.

tinct possibility that loss of axonal function after glutamate exposure may also be caused by direct activation of axonal receptors leading to (possibly focal) axoplasmic $\mathrm{Ca}^{2+}$ deregulation. Curiously, immature premyelinated fibers are reported to suffer ischemic injury independently of glutamate receptors. ${ }^{33}$ Contrasted with our findings in mature myelinated axons, this may indicate that myelination induces expression and clustering of axonal glutamate receptors, as it does other nodal and perinodal proteins. ${ }^{44}$ Immunohistochemistry of dorsal column axons showed colocalized Glur6/7 and nNOS clusters sparsely distributed along axon cylinders as has been reported previously for $\mathrm{Ca}_{\mathrm{v}}$ and RyR clusters. ${ }^{30}$ Our results are consistent with the following proposed feed-forward mechanism (Fig 6): Activation of GluR6-containing kainate receptors induces a local depolarization of the internodal axolemma, together with a small amount of $\mathrm{Ca}^{2+}$ influx from a restricted periaxonal space. The local axonal $\mathrm{Ca}^{2+}$ microdomain promotes $\mathrm{NO}$ synthesis by nNOS, and the local depolarization activates L-type $\mathrm{Ca}^{2+}$ channels, thereby opening ryanodine receptors on subaxolemmal endoplasmic reticulum, culminating in a much larger $\mathrm{Ca}^{2+}$ transient than would be possible solely by influx of this ion. This is consistent with previous observations of kainate receptor-mediated depolarization of central axons. ${ }^{43}$
Our electrophysiological recordings, which showed that functional injury induced by kainate receptor stimulation was significantly reduced by blocking L-type $\mathrm{Ca}^{2+}$ channels, emphasize two important points. First, given that activation of these receptors in otherwise uninjured dorsal columns results in significant functional impairment indicates that the observed $\mathrm{Ca}^{2+}$ increase induced by this treatment is pathophysiologically significant and raises the distinct possibility that exposure of axons to glutamate in inflammatory or ischemic lesions, for instance, may be directly damaging to axons. Second, the significant reduction in GluR6-mediated electrophysiological injury conferred by an L-type $\mathrm{Ca}^{2+}$ channel blocker further strengthens the functional connection between these receptors and $\mathrm{Ca}^{2+}$ channels, as suggested by the $\mathrm{Ca}^{2+}$ imaging experiments (see Fig 2) and summarized in the proposed model (see Fig 6).

The effect of NO is curious, though this modulator may function to increase the "gain" of the $\mathrm{Ca}_{\mathrm{v}}-\mathrm{RyR}$ coupling mechanism, possibly by upregulation of RyR activity. ${ }^{45}$ This may be necessary to ensure the fidelity of this signaling cascade, because unlike neurons and muscle cells that are not ensheathed, voltage-gated proteins such as $\mathrm{Ca}_{\mathrm{v}} \mathrm{s}$, which are localized to the internodal axolemma of myelinated fibers, likely experience smaller electric-field fluctuations because of the overlying myelin. Given the known promiscuous actions of NO (and its highly reactive derivative peroxynitrite), it is possible that other ion transporters, which are important for axonal impulse propagation (eg, voltagegated $\mathrm{Na}$ and $\mathrm{K}$ channels, Na-K-ATPase ${ }^{46}$ ), may be modulated as well in response to kainate receptor/ nNOS activation. Thus, central myelinated axons contain functional complexes of several signaling proteins that are arranged in close proximity (eg, GluR6/7, nNOS, and $\mathrm{Ca}_{\mathrm{v}} 1.2$; see Fig 4; L-type $\mathrm{Ca}^{2+}$ channels and ryanodine receptors ${ }^{30}$ ), allowing local NO production and depolarization to modulate their function. The purpose of such clusters in mature myelinated fibers is currently unknown; in developing axons, however, growth cone dynamics have been shown to be dependent on glutamate receptor activation and release of $\mathrm{Ca}^{2+}$ from intraaxonal $\mathrm{Ca}^{2+}$ stores, ${ }^{47}$ indicating that ionotropic glutamate receptors and $\mathrm{Ca}^{2+}$ signaling from axonal stores are functionally related from an early developmental age. Their precise physiological roles in adulthood will require further study. Scaffolding of axonal receptors and effectors such as nNOS in close proximity is reminiscent of the organization of signaling molecules at the postsynaptic density in neurons, ${ }^{48,49}$ and it hints at highly specialized and complex machinery assembled along the internodal axolemma, where little active signaling was thought to take place.

Both glutamate- and NO-dependent toxicity are in- 


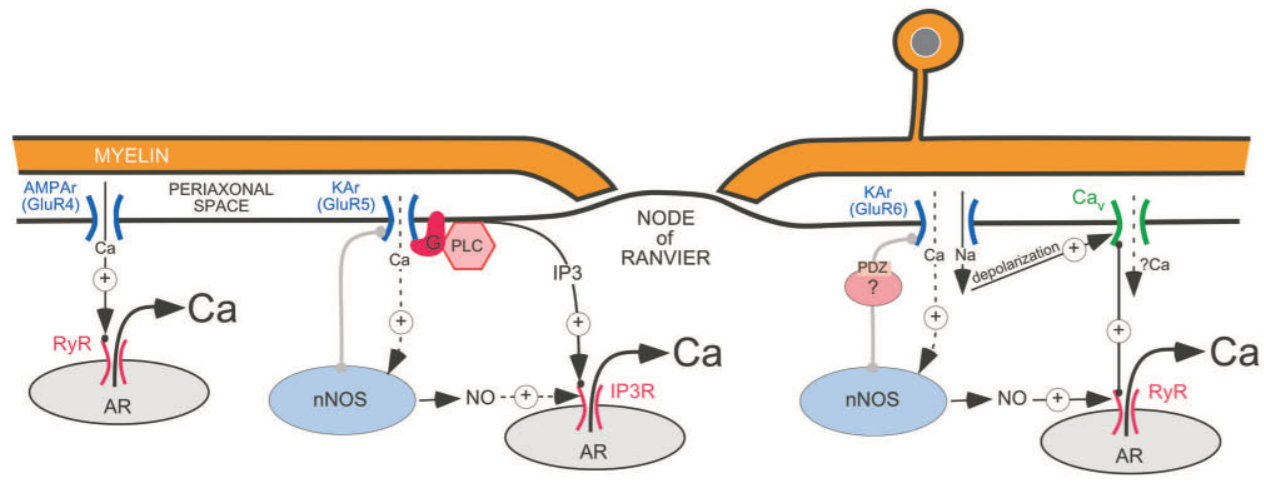

Fig 6. Proposed arrangement of signaling molecules in internodal axonal nanocomplexes. GluR4 AMPA receptors permeate small amounts of $\mathrm{Ca}^{2+}$, which, in turn, release $\mathrm{Ca}^{2+}$ from the axoplasmic reticulum (AR) via "cardiac-type" $\mathrm{Ca}^{2+}$-induced $\mathrm{Ca}^{2+}$ release. ${ }^{51}$ Axonal $\mathrm{Ca}^{2+}$ increases from activation of GluR5 kainate receptors occur mainly via a G-protein-coupled, phospholipase $C$ (PLC)-dependent synthesis of $I P_{3}$, which, in turn, activates $I P_{3}$ receptors on the AR; this latter mechanism is partially dependent on NO, which is synthesized by $n N O S$, itself activated by small amounts of $\mathrm{Ca}^{2+}$ entry via the GluR5 receptor; the locally produced NO may then further upregulate $I P_{3}$ receptor activity. ${ }^{51}$ Activation of GluR6 kainate receptors induces a local depolarization and a small amount of $\mathrm{Ca}^{2+}$ entry. The depolarization activates $L$-type $\mathrm{Ca}^{2+}$ channels $(\mathrm{Ca}$ ), whereas the kainate receptor-mediated $\mathrm{Ca}^{2+}$ influx stimulates $n N O S$, which is scaffolded in the vicinity of the receptor. Similarly to GluR5 receptors, locally generated NO may upregulate the activity of ryanodine receptors, which are activated by the depolarization-induced conformational change of the $\mathrm{Ca}^{2+}$ channel, leading to release of $\mathrm{Ca}^{2+}$ from the AR. Together, these mechanisms, possibly activated by axonally released glutamate, serve to amplify the axonal $\mathrm{Ca}^{2+}$ signal, which would normally be weak because of the limited quantity of ion available in the narrow periaxonal space.

volved in white matter injury, and particularly in axonal damage, in crippling disorders such as multiple sclerosis. ${ }^{34}$ The signaling clusters described in this report likely promote and amplify local $\mathrm{Ca}^{2+}$ transients, and may have profound implications for axonal pathophysiology. The local release of potentially high concentrations of $\mathrm{Ca}^{2+}$ through activation of such axonal "nanocomplexes" may play an important role in the genesis of focal swellings and irreversible axonal transections ${ }^{50}$ that render the entire fiber nonfunctional. The surprisingly complex interaction of glutamate, $\mathrm{NO}$, voltage-gated $\mathrm{Ca}^{2+}$ channels, and internal $\mathrm{Ca}^{2+}$ stores in axons may paradoxically present unforeseen opportunities for the development of novel therapeutic strategies.

This work was supported by the NIH (National Institute of Neurological Diseases and Stroke, P.K.S., B.D.T.), Canadian Institutes of Health Research (P.K.S., G.W.Z.), Heart and Stroke Foundation of Ontario Center for Stroke Recovery (P.K.S.), Canadian Stroke Network (P.K.S.), HSFO (Heart and Stroke Foundation of Ontario) Career Investigator Award (P.K.S.), AHFMR (Alberta Heritage Foundation for Medical Research) Scientist Award (P.K.S., G.W.Z.), and CCRI (Center for Catalysis Research and Innovation collaborative fund) (A.B.). G.W.Z. and P.K.S. are Canada Research Chairs (Tier I).

\section{Acknowledgment}

We thank Drs B. Barres, E. Peles, and M. Rasband for critical reading of the manuscript, and Dr J. McRory for assistance with coimmunoprecipitations.

\section{References}

1. Lipton SA, Rosenberg PA. Excitatory amino acids as a final common pathway for neurologic disorders. N Engl J Med 1994;330:613-622.

2. Stys PK, Waxman SG, Ransom BR. Ionic mechanisms of anoxic injury in mammalian CNS white matter: role of $\mathrm{Na}^{+}$ channels and $\mathrm{Na}+-\mathrm{Ca} 2+$ exchanger. J Neurosci 1992;12: $430-439$.

3. Fern R, Ransom BR, Waxman SG. Voltage-gated calcium channels in CNS white matter: role in anoxic injury. J Neurophysiol 1995;74:369-377.

4. Imaizumi T, Kocsis JD, Waxman SG. Anoxic injury in the rat spinal cord-pharmacological evidence for multiple steps in Ca2+-dependent injury of the dorsal columns. J Neurotrauma 1997;14:299-311.

5. Stys PK. General mechanisms of axonal damage and its prevention. J Neurol Sci 2005;233:3-13.

6. Agrawal SK, Fehlings MG. Role of NMDA and non-NMDA ionotropic glutamate receptors in traumatic spinal cord axonal injury. J Neurosci 1997;17:1055-1063.

7. Li S, Mealing GA, Morley P, et al. Novel injury mechanism in anoxia and trauma of spinal cord white matter: glutamate release via reverse $\mathrm{Na}+$-dependent glutamate transport. J Neurosci 1999;19:RC16.

8. Ouardouz M, Malek S, Coderre E, et al. Complex interplay between glutamate receptors and intracellular $\mathrm{Ca} 2+$ stores during ischaemia in rat spinal cord white matter. J Physiol 2006; 577:191-204.

9. Tekkok SB, Goldberg MP. AMPA/kainate receptor activation mediates hypoxic oligodendrocyte death and axonal injury in cerebral white matter. J Neurosci 2001;21:4237-4248.

10. Tekkok SB, Ye Z, Ransom BR. Excitotoxic mechanisms of ischemic injury in myelinated white matter. J Cereb Blood Flow Metab 2007;1540-1552. 
11. Kanellopoulos GK, Xu XM, Hsu CY, et al. White matter injury in spinal cord ischemia: protection by AMPA/kainate glutamate receptor antagonism. Stroke 2000;31:1945-1952.

12. Wrathall JR, Choiniere D, Teng YD. Dose-dependent reduction of tissue loss and functional impairment after spinal cord trauma with the AMPA/kainate antagonist NBQX. J Neurosci 1994;14:6598-6607.

13. Pitt D, Werner P, Raine CS. Glutamate excitotoxicity in a model of multiple sclerosis. Nat Med 2000;6:67-70.

14. Smith T, Groom A, Zhu B, et al. Autoimmune encephalomyelitis ameliorated by AMPA antagonists. Nat Med 2000;6: $62-66$.

15. McDonald JW, Althomsons SP, Hyrc KL, et al. Oligodendrocytes from forebrain are highly vulnerable to AMPA/kainate receptor-mediated excitotoxicity. Nat Med 1998;4:291-297.

16. Li S, Stys PK. Mechanisms of ionotropic glutamate receptormediated excitotoxicity in isolated spinal cord white matter. J Neurosci 2000;20:1190-1198.

17. Domercq M, Etxebarria E, Perez-Samartin A, et al. Excitotoxic oligodendrocyte death and axonal damage induced by glutamate transporter inhibition. Glia 2005;52:36-46.

18. Matute C. Characteristics of acute and chronic kainate excitotoxic damage to the optic nerve. Proc Natl Acad Sci U S A 1998;95:10229-10234.

19. Fowler JH, McCracken E, Dewar D, et al. Intracerebral injection of AMPA causes axonal damage in vivo. Brain Res 2003; 991:104-112.

20. Matute C, Domercq M, Sanchez-Gomez MV. Glutamatemediated glial injury: mechanisms and clinical importance. Glia 2006;53:212-224.

21. Karadottir R, Cavelier P, Bergersen LH, et al. NMDA receptors are expressed in oligodendrocytes and activated in ischaemia. Nature 2005;438:1162-1166.

22. Salter MG, Fern R. NMDA receptors are expressed in developing oligodendrocyte processes and mediate injury. Nature 2005; 438:1167-1171.

23. Micu I, Coderre E, Jiang Q, et al. NMDA receptors mediate $\mathrm{Ca}$ accumulation in central nervous system myelin during chemical ischemia. Nature 2006;439:988-992.

24. David JC, Yamada KA, Bagwe MR, et al. AMPA receptor activation is rapidly toxic to cortical astrocytes when desensitization is blocked. J Neurosci 1996;16:200-209.

25. Matute C, Alberdi E, Domercq M, et al. Excitotoxic damage to white matter. J Anat 2007;210:693-702.

26. McCracken E, Fowler JH, Dewar D, et al. Grey matter and white matter ischemic damage is reduced by the competitive AMPA receptor antagonist, SPD 502. J Cereb Blood Flow Metab 2002;22:1090-1097.

27. Verdoorn TA, Johansen TH, Drejer J, et al. Selective block of recombinant glur6 receptors by NS-102, a novel non-NMDA receptor antagonist. Eur J Pharmacol 1994;269:43-49.

28. Mayer ML, Ghosal A, Dolman NP, et al. Crystal structures of the kainate receptor GluR5 ligand binding core dimer with novel GluR5-selective antagonists. J Neurosci 2006;26:2852-2861.

29. Donevan SD, Beg A, Gunther JM, et al. The methylglutamate, SYM 2081, is a potent and highly selective agonist at kainate receptors. J Pharmacol Exp Ther 1998;285:539-545.

30. Ouardouz M, Nikolaeva M, Coderre E, et al. Depolarizationinduced $\mathrm{Ca} 2+$ release in ischemic spinal cord white matter involves $\mathrm{L}$-type $\mathrm{Ca} 2+$ channel activation of ryanodine receptors. Neuron 2003;40:53-63.
31. Rozas JL, Paternain AV, Lerma J. Noncanonical signaling by ionotropic kainate receptors. Neuron 2003;39:543-553.

32. Paternain AV, Cohen A, Stern-Bach Y, et al. A role for extracellular $\mathrm{Na}+$ in the channel gating of native and recombinant kainate receptors. J Neurosci 2003;23:8641-8648.

33. McCarran WJ, Goldberg MP. White matter axon vulnerability to AMPA/kainate receptor-mediated ischemic injury is developmentally regulated. J Neurosci 2007;27:4220-4229.

34. Matute C, Alberdi E, Domercq M, et al. The link between excitotoxic oligodendroglial death and demyelinating diseases. Trends Neurosci 2001;24:224-230.

35. Flogel U, Merx MW, Godecke A, et al. Myoglobin: a scavenger of bioactive NO. Proc Natl Acad Sci U S A 2001;98:735-740.

36. Rajanayagam MA, Li CG, Rand MJ. Differential effects of hydroxocobalamin on NO-mediated relaxations in rat aorta and anococcygeus muscle. Br J Pharmacol 1993;108:3-5.

37. Pinheiro P, Mulle C. Kainate receptors. Cell Tissue Res 2006; 326:457-482.

38. Stys PK, Ransom BR, Waxman SG. Compound action potential of nerve recorded by suction electrode: a theoretical and experimental analysis. Brain Res 1991;546:18-32.

39. Matute C, Sanchez-Gomez MV, Martinez-Millan L, et al. Glutamate receptor-mediated toxicity in optic nerve oligodendrocytes. Proc Natl Acad Sci U S A 1997;94:8830-8835.

40. Deng W, Rosenberg PA, Volpe JJ, et al. Calcium-permeable AMPA/kainate receptors mediate toxicity and preconditioning by oxygen-glucose deprivation in oligodendrocyte precursors. Proc Natl Acad Sci U S A 2003;100:6801-6806.

41. Ziskin JL, Nishiyama A, Rubio M, et al. Vesicular release of glutamate from unmyelinated axons in white matter. Nat Neurosci 2007;10:321-330.

42. Kukley M, Capetillo-Zarate E, Dietrich D. Vesicular glutamate release from axons in white matter. Nat Neurosci 2007;10: 311-320.

43. Semyanov A, Kullmann DM. Kainate receptor-dependent axonal depolarization and action potential initiation in interneurons. Nat Neurosci 2001;4:718-723.

44. Poliak S, Peles E. The local differentiation of myelinated axons at nodes of Ranvier. Nat Rev Neurosci 2003;4:968-980.

45. Hart JD, Dulhunty AF. Nitric oxide activates or inhibits skeletal muscle ryanodine receptors depending on its concentration, membrane potential and ligand binding. J Membr Biol 2000; 173:227-236.

46. Pacher P, Beckman JS, Liaudet L. Nitric oxide and peroxynitrite in health and disease. Physiol Rev 2007;87:315-424.

47. Yamada RX, Sasaki T, Ichikawa J, et al. Long-range axonal calcium sweep induces axon retraction. J Neurosci 2008;28: 4613-4618.

48. Aarts M, Liu Y, Liu L, et al. Treatment of ischemic brain damage by perturbing NMDA receptor- PSD-95 protein interactions. Science 2002;298:846-850.

49. Liu XM, Pei DS, Guan QH, et al. Neuroprotection of TatGluR6-9c against neuronal death induced by kainate in rat hippocampus via nuclear and non-nuclear pathways. J Biol Chem 2006;281:17432-17445.

50. Trapp BD, Peterson J, Ransohoff RM, et al. Axonal transection in the lesions of multiple sclerosis. N Engl J Med 1998;338: $278-285$

51. Ouardouz M, Coderre E, Zamponi GW, et al. Glutamate receptors on myelinated spinal cord axons: II. AMPA and GluR5 receptors. Ann Neurol 2009;65:160-166. 